\title{
HOW TO MANAGE SUDDEN IVC DECOIMPRESSION IN CASE OF A LARGE RETROPERITONEAL MYYLOLIPOIMA.
}

KEY WORDS:

Dr. Nina M. Shah

\section{Dr. Priyanka}

Warde*

Dr. Hiral C. Chauhan

\section{INTRODUCTION:}

myelolipoma is a rare lesion, benign in nature, and composed of variable mixture of mature adipose and hematopoietic elements. It can be adrenal or extraadrenal.It was initially described by Gierke in 1905 and subsequently termed as formations myelolipomatoses by Oberling in 1929 . In the past, these lesions used to be primarily detected at autopsy or in conditions where massive growth or an alteration in the hormonal production led to clinical presentation. However, in recent times, as a result of widespread use of noninvasive cross sectional imaging modalities such as USG ,CT and MRI incidental detection is more common. The tumor appears to affect men and women equally and most commonly found between the fifth and the seventh decade of life. Accounting for $3-5 \%$ of all primary tumors of the adrenals, the true incidence of these tumors is not known, although it is thought to be $0.08 \%-0.4 \%$, with increased incidence noted in the later decades of life. The majority of these tumors are unilateral, small, and asymptomatic although some bilateral myelolipomas have been described. They are generally nonsecreting in nature, and only one case of secreting myelolipoma has been reported so far. After surgical resection, these lesions tend to not recur. large tumors are compressing and displacing the IVC causing renal vein thrombosis and ivc thrombosis sometimes so after excision of such tumor sudden ivc decompression can cause increased. Preload and cardiac failure.and renal parenchymal congestion due to venous thrombosis whichj can reduce GFR and reduce urine output.

\section{Case report:}

31 year female patient presented to surgical OPD to take consult about incidental finding of large mass originating from liver in routine antennal checkup at $5^{\text {th }}$ month of pregnancy. We have done ultrasound which is suggestive of suprarenal mass patient was kept under regular follow up and checked for any increase in size of mass but there is no changes in mass .patient deliver baby with normal vaginal delivery ,after postpartum 7 months patient came back with right sided abdominal lump. No complaint of abdominal pain ,vomiting ,headache ,palpitation ,diarrhea ,constipation ,fever, generalized weakness and weight loss. Past history of cesarean section before 8 years .

On per abdominal examination $20 * 10 * 8 \mathrm{CM}$ spherical firm lump palpable with smooth margins over right side of abdomen which moves with respiration and bimanually palpable.

\begin{tabular}{|l|l|l|}
\hline Date & investigation & Findings \\
\hline $13 / 1 / 202$ & USG & $\begin{array}{l}30 * 12 \mathrm{~cm} \text { sized hyperechoic lesion } \\
\text { in right hypochondriac region upto } \\
\text { RIF s/p/o adenoma with origin of } \\
\text { liver }\end{array}$ \\
\hline $19 / 1 / 202$ & MRI & $\begin{array}{l}15.6 * 14 * 25 \mathrm{~cm} \text { large } \\
\text { retroperitoneal mass of possibility } \\
\text { of adrenal myelolipoma likely over } \\
\text { adrenal atypical adenoma. }\end{array}$ \\
\hline $3 / 2 / 2020$ & USG & $\begin{array}{l}16^{*} 18^{*} 30 \mathrm{~cm} \text { well defined } \\
\text { homogenous hyperechoic lesion } \\
\text { from RHC to right lumbar region } \\
\text {-right kidney displaced medially } \\
\text { and right suprarenal not visualized } \\
\text { separately. }\end{array}$ \\
\hline $18 / 1 / 202$ & $\begin{array}{l}\text { CECT } \\
\text { abdomen } \\
\text { and pelvis }\end{array}$ & $\begin{array}{l}\text { 23*16*18cm suprarenal mass with } \\
\text { predominant fatty component. } \\
\text { thick internal septa with dense non } \\
\text { enhancing contents suggests } \\
\text { liposarcoma with internal } \\
\text { haemorrhage. }\end{array}$ \\
\hline $25 / 1 / 202$ & $\begin{array}{l}\text { CECT } \\
\text { review }\end{array}$ & $\begin{array}{l}\text { Lesion appear to abut and } \\
\text { displaces right renal vein towards } \\
\text { left and anteriorly. Approximately } \\
16 \text { mm long segment of right renal } \\
\text { vein is showing partial thrombosis } \\
21 \text { mm from renal hilum.lesion } \\
\text { abuts and displaces IVC to left. }\end{array}$ \\
\hline 1
\end{tabular}

Plasma free metanephrine, cortisol levels and 24 hour urinary vanilmandelic acid levels normal.

\section{Procedure:}

preoperative ureteric catheterization done.after midline laparotomy incision approximately $30 * 20 * 15 * \mathrm{~cm}$ mass was seen covering right side of abdomen overlying peritoneal layer was opened and underlying mass was separated from adhesions from liver diaphragm superiorly and from retroperitoneum posteriorly right kidney was not palpable in right renal fossa it was displaced on left side superiorly ,IVC was compressed and displaced by compression effect of mass. mass was excised from surrounding after removal of mass right kidney came to normal position and right side suprarenal vessels re doubly ligated and hoeamostasis acheived retroperitoneal area checked for any tumor bits. drain placement in right renal fossa done and ureteric catherters were removed and patient shifted to ward.

Postoperative course:

\begin{tabular}{|l|l|l|l|l|l|}
\hline Day & Vitals & Event & Input & output & Management \\
\hline 0 & $\begin{array}{l}\text { Pulse rate 130/min } \\
\text { Bp 128/7 2mmhg } \\
\text { Spo2 98\% on air }\end{array}$ & Mild hematuria i & Input 1500cc & $\begin{array}{l}\text { U/O 1100 } \\
\text { D/O } \\
75 \mathrm{cc}\end{array}$ & $\begin{array}{l}\text { Injectable tranexa, botropase, vitamin K } \\
\text { started. } \\
\text { Comment :we should not remove ureteric } \\
\text { catheter if hematuria was present } \\
\text { intraoperatively. }\end{array}$ \\
\hline
\end{tabular}




\begin{tabular}{|c|c|c|c|c|c|}
\hline 1 & $\begin{array}{l}\text { Pulse rate } 156 / \mathrm{min} \\
\text { Bp } 110 / 70 \mathrm{mmh} \\
\text { Spo2 } 82 \% \text { on air }\end{array}$ & $\begin{array}{l}\text { Sudden tachycardia with } \\
\text { mild hypotension at } \\
\text { 4P.M. } \\
\text { Fall in spo2 upto } 82 \% \text { at } \\
\text { 6P.M. }\end{array}$ & \begin{tabular}{l|} 
Input \\
$1300 \mathrm{cc}$
\end{tabular} & $\begin{array}{l}\text { U/O } 1400 \\
\text { D/O } 75 C C\end{array}$ & $\begin{array}{l}\text { Tramadol injectable added as analgesic } \\
\text {.Patient shifted to ICU on Oxygen mask. } \\
\text { Comment: medicine reference done and } \\
\text { metoprolol started and Inderal stopped. }\end{array}$ \\
\hline 8A.M. & \begin{tabular}{|l|} 
Pulse rate $130 / \mathrm{min}$ \\
Bp $110 / 70 \mathrm{mmhg}$ \\
Spo2 97 on o2 mask \\
\\
Pulse rate $105 / \mathrm{min}$ \\
Bp $80 / 54 \mathrm{mmhg}$ \\
Spo2 $98 \%$ on o2 mask
\end{tabular} & $\begin{array}{l}\text { Sudden decrease in } \\
\text { urine output with mild } \\
\text { abdominal distension } \\
\text { urea } \\
\text { creatinine } 2.5 \\
\mathrm{NA}+ \\
\mathrm{K}+ \\
\text { Persistent hypotension } \\
\text { present }\end{array}$ & \begin{tabular}{l|} 
input \\
$1350 \mathrm{~m}$ \\
1
\end{tabular} & $\begin{array}{l}\text { u/o } 600 \mathrm{ml} \\
\mathrm{d} / \mathrm{o} 20 \mathrm{cc} \text { serous }\end{array}$ & \begin{tabular}{|l|} 
Thyroid function test done. \\
Usg for collection suggests $7 * 7 * 6 \mathrm{~cm}$ \\
collection in right suprarenal region \\
renal vessel doppler done for \\
thrombosis which was normal \\
Injectable NORADRENALINE 4 ampule \\
in50 cc NS started at rate. Of $4 \mathrm{cc} /$ hour \\
abdominal binder was given. \\
comment: iv fluids given $1000 \mathrm{ml}$ \\
overnight decrease in urine output may \\
be because of hypotension and prerenal \\
cause of altered renal function \\
we should have checked for catheter \\
blockage also.
\end{tabular} \\
\hline $\begin{array}{l}3 \\
8 \mathrm{AM}\end{array}$ & $\begin{array}{l}\text { Pulse rate } 88 / \mathrm{min} \\
\text { Bp } 108 / 70 \mathrm{mmhg} \\
\text { Spo2 } 99 \% \text { on air }\end{array}$ & $\begin{array}{l}\text { On per abdomen } \\
\text { palpation bladder is } \\
\text { overdistended }\end{array}$ & $\begin{array}{l}\text { Input } \\
1800 \mathrm{cc}\end{array}$ & $\begin{array}{l}\text { u/o } 200 \mathrm{cc} \text { in } 12 \mathrm{hour} \\
\mathrm{D} / \mathrm{O} 30 \mathrm{cc} \\
\text { Output } 1330 \\
\\
\mathrm{U} / \mathrm{O} \\
1200 \mathrm{cc} \\
\mathrm{D} / \mathrm{O} \\
30 \mathrm{cc}\end{array}$ & \begin{tabular}{|l|} 
Urinary catheter removed and \\
reinserted \\
Injectable NORADRENALINE reduced to \\
2cc/hour \\
tablet ALTROXINE 50micrograms started \\
ryels tube removed \\
started orally liquid diet
\end{tabular} \\
\hline 4 & $\begin{array}{l}\text { Pulse rate } 88 / \mathrm{min} \\
\text { Bp } 110 / 70 \mathrm{mmhg}\end{array}$ & $\begin{array}{l}\text { Abdominal girth normal } \\
\text { Serum creatinine } 2.5\end{array}$ & \begin{tabular}{|l|} 
Input \\
$1780 \mathrm{cc}$
\end{tabular} & $\begin{array}{l}\text { U/O } 2000 \\
\text { Output } \\
2200 \mathrm{cc}\end{array}$ & $\begin{array}{l}\text { DRAIN REMOVED } \\
\text { Injectable noradrenaline reduced to } \\
0.5 \mathrm{cc} / \text { hour } \\
\text { Started soft diet orally }\end{array}$ \\
\hline 5 & Vitally stable & $\begin{array}{l}\text { Serum creatinine } 1.2 \\
\text { Patients hemoglobin fall } \\
\text { upto } 8.5 \mathrm{gm} / \mathrm{dl} \text { from } \\
1 \mathrm{lgm} / \mathrm{dl}\end{array}$ & \begin{tabular}{l|}
$\begin{array}{l}\text { Adequ } \\
\text { ate }\end{array}$ \\
\end{tabular} & adequate & $\begin{array}{l}\text { No noradrenaline support required } \\
\text { Biopsy :denovo myelolipoma } \\
\text { Comment:may be actively causing } \\
\text { heamatopoesis which was stopped after } \\
\text { tumor removal, } \\
\text { Search for bonemarrow functioning } \\
\text { reticulocyte count done:normal }\end{array}$ \\
\hline 6 & Vitally stable & - & \begin{tabular}{|l|} 
adequ \\
ate
\end{tabular} & adequate & $\begin{array}{l}\text { Started oral hematinics } \\
\text { Plan for discharge }\end{array}$ \\
\hline
\end{tabular}

\section{DISCUSSION}

There are several theories for the etiology and the natural history of adrenal myelolipoma. However, the most widely accepted theory is adrenocortical cell metaplasia in response to stimuli, such as necrosis, inflammation, infection, or stress . The conditions often associated with adrenal myelolipomas include Cushing's disease, obesity, hypertension, and diabetes which can be characterized as major adrenal stimuli .Stressful life style and unbalanced diet as factors that may be involved in the pathogenesis of this tumor.

Management of adrenal myelolipoma should be considered on individual basis. Small lesions, which are asymptomatic and measure less than $5 \mathrm{~cm}$, should be monitored over a period of 1-2 years with imaging controls. It is suggested that symptomatic tumors or myelolipomas larger than $7 \mathrm{~cm}$ should be surgically excised so as to prevent a urological emergency since there are reports of spontaneous rupture and hemorrhage of the mass presented with life-threatening cardiovascular shock. In cases such as ours, extraperitoneal approach is preferable than midline incision as it leads to quicker recovery of the patient and lesser postoperative complications.

This approach, however, is not indicated for masses larger |www.worldwidejournals.com | than $10 \mathrm{~cm}$ or in cases where there are adhesions and infiltration of the surrounding structures . extra-adrenal myelolipoma - Extra-adrenal myelolipoma is a rare, typically unilateral, benign mesenchymal lesion, containing adipose and hematopoietic tissue, that can occur in the retroperitoneum, most commonly in the presacral region. Most patients with extra-adrenal myelolipoma are asymptomatic, the lesion usually being identified as an incidental finding on an imaging examination, although some patients present with abdominal pain, due to hemorrhage, tumor infarction, or extrinsic compression the presence of hematopoietic components confirms the diagnosis of extraadrenal myelolipoma.

Here Extrinsic compression is seen of IVC and renal vesssels.due to compression there was a partial thrombus formation in right renal vein after removal of tumor there was release of compression so compliance of vein increased and vein become dilated and peripheral pooling occurred and it reduced the preload and cardiac output hence hypotension occurred and it will also affected kidney and renal output reduced which was normalised after 2 days of adaptation of normal venous compliance during this period patient was kept on vasopressor support. 


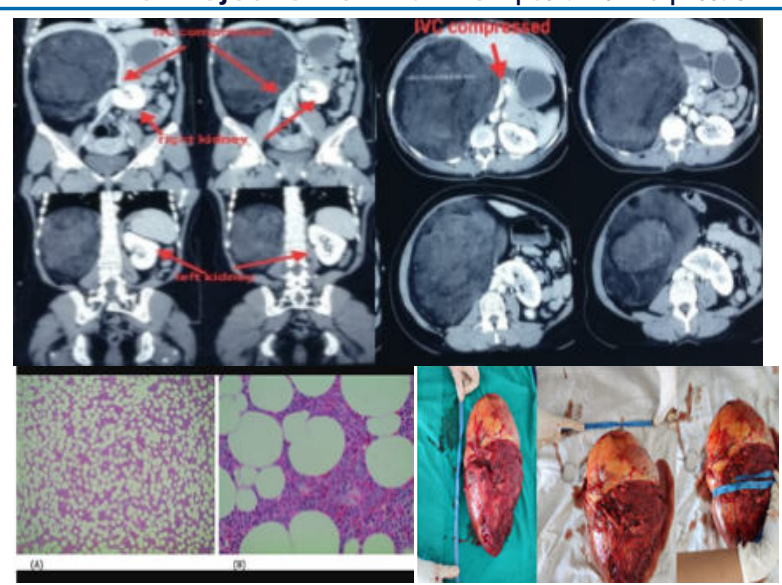

CONCLUSION:

IVC decompression can be managed by increased fluids intravenously and vasopressor support after removal of giant retroperitoneal myelolipoma. 